\title{
Cliff Roosting by Migrant Semipalmated Sandpipers, Calidris pusilla, at Farrier's Cove, Shepody Bay, New Brunswick
}

\author{
Colin M. MacKinnon ${ }^{1}$, Julie Dulude ${ }^{2}$, Andrew C. Kennedy ${ }^{1}$, Sophie J. E. Surette ${ }^{3}$, and Peter \\ W. HICKLIN ${ }^{1}$
}

${ }^{1}$ Environment Canada, Canadian Wildlife Service, P. O. Box 6227, Sackville, New Brunswick E4L 1G6 Canada

21520 De Moscou, Drummondville, Québec J2C 8C5 Canada

${ }^{3} 1590$ A Larch Street, Halifax, Nova Scotia B3H 3W8 Canada

MacKinnon, Colin M., Julie Dulude, Andrew C. Kennedy, Sophie J. E. Surette and Peter W. Hicklin. 2008. Cliff roosting by migrant Semipalmated Sandpipers, Calidris pusilla, at Farrier's Cove, Shepody Bay, New Brunswick. Canadian Field-Naturalist 122(3): 274-276.

An observation of Semipalmated Sandpipers roosting on a cliff face in Shepody Bay, New Brunswick, suggests changes from "traditional" roosting sites. Sandpipers may be altering their roosting patterns due to pressures from avian predators such as the recent, and successful, re-introduction of the Peregrine Falcon.

Key Words: Semipalmated Sandpiper, Calidris pusilla, Peregrine Falcon, Falco peregrinus, roosting, RAMSAR (wetland of international importance), WHSRN (Western Hemisphere Shorebird Reserve Network), Farrier's Cove, Shepody Bay, New Brunswick.

The life history of the Semipalmated Sandpiper (Calidris pusilla) has been well documented (GrattoTrevor 1992). Furthermore, detailed studies describe the southerly fall migration of these birds (Morrison 1977; Elliot 1977; Harrington and Morrison 1979; Hicklin and Smith 1979; Hicklin 1981*; Hicklin and Smith 1984; Hicklin 1987) and their foraging ecology during stopover, on the macro-tidal (14 m) mudflats of the Bay of Fundy (Hicklin and Smith 1979; Boates 1980; Hicklin 1981*, 1987, 1988; Sprague 2006; Sprague et al. 2008). Consequently, in 1987, Shepody Bay, New Brunswick, was recognized as a RAMSAR site (wetland of international importance) (RAMSAR Sites of Atlantic Canada 1994*) and designated as part of the Western Hemisphere Shorebird Reserve Network (WHSRN) (Hicklin 1988).

Over the past thirty years, many studies have focused on shorebirds in Shepody Bay, including the long-term monitoring of roosting sandpipers and shorebird banding. Over this same time period, there has been an increase in ecotourism directed towards viewing the large flocks of sandpipers that roost on the beaches in Shepody Bay during high tide. For example, throughout July and August each year, 10000+ tourists visit the "traditional" roost sites at Johnson's Mills $\left(45^{\circ} 50^{\prime} \mathrm{N}\right.$,

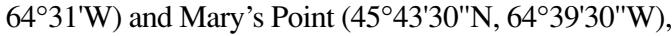
New Brunswick, to observe and photograph these large flocks of birds (unpublished visitor data from The Nature Conservancy of Canada Shorebird Interpretation Centre at Johnson's Mills and the Mary's Point Shorebird Research Station at Mary's Point). These roost sites consist of exposed sand and/or cobble beaches where visibility of approaching predators would appear to be good. Roosting numbers of Semipalmated Sandpipers on these beaches have been estimated at up to 200000 birds in a single flock (see Morrison 1977), and PH estimated a flock at 300000 birds at Johnson's Mills in 2006. Roost site selection by these sandpipers is influenced by tidal height since many of these shorelines can be underwater during "spring" (higher high-water) tides on some days. This lack of roosting locations, when "traditional" beaches have been inundated at the highest tide has resulted in sandpipers roosting at unusual locations such as on the secondary gravel road (Route \#935) at Johnson's Mills in some years. In 1980, approximately 1500 birds were killed when a motor vehicle drove through a roosting flock (Hicklin 1981*) and on 22 August 2005, over 5000 birds were observed roosting on this same road, blocking vehicle traffic (under similar tidal conditions). Generally, shorebird roosting sites have the following characteristics: they (i) remain uncovered by the high tides; (ii) are relatively close to foraging areas; (iii) are away from areas of high disturbance; and (iv) permit unobstructed lateral vision of areas adjacent to the birds (see Elliot 1977). Within the past 5 to 10 years, use of some of these "traditional" sites by Semipalmated Sandpipers appears to be in decline as other, little used or previously unrecorded, roosting sites are frequented by significant numbers $(<10000)$ of birds (unpublished data). Although the true cause(s) is/are unclear, it has been speculated that the successful reintroduction of the Peregrine Falcon (Falco peregrinus) to eastern Canada (Amirault 2003), as well as other disturbance pressures (bird watchers and beach users), have altered the shorebirds' roosting site selection and behaviour; although sandpipers are still roosting at some sites with high numbers of avian predators (see Sprague 2006; Sprague et al. 2008). Prior to a successful re-introduction program throughout the 1980s, the last recorded Peregrine Falcon nest in Maritime Canada was reported in 1955 at Cape d'Or in Nova Scotia (Amirault 2003). By 1991, the falcons had established (or re-established) three active nest sites in the greater Shepody Bay area (Amirault 1997) and they have been active nearly every year since. These nest sites are all 


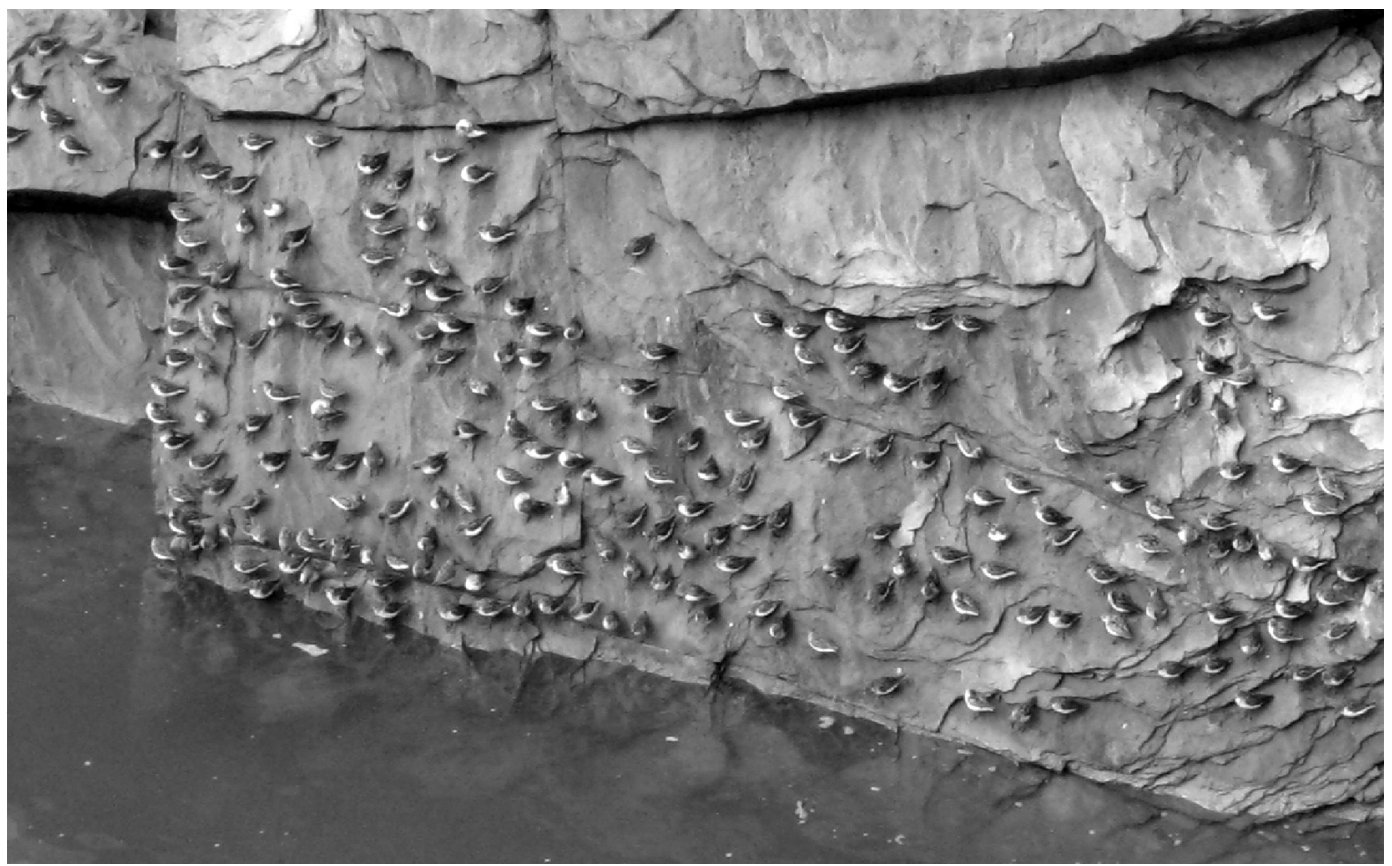

FIGURE 1. Portion of a flock of 257 Semipalmated Sandpipers (Calidris pusilla) roosting on a vertical sandstone cliff at high tide, 23 July 2008, in Farrier's Cove, Shepody Bay, New Brunswick (Julie Dulude photo).

within the sandpipers' foraging range of the Shepody Bay mud flats' and attacks by falcons on roosting and foraging shorebirds are well-documented (Campbell 1999; Beauchamp and Ruxton 2008; Hicklin unpublished) and have become an almost daily occurrence wherever shorebirds concentrate in Shepody Bay. Conklin et al. (2008), while studying roost variations in Dunlin (Calidris alpina) in California, and Sprague et al. (2008) in the upper Bay of Fundy also noted the dynamic nature of roost use and roost suitability. They further noted that the movement of Dunlin amongst roosts was most strongly influenced by avian predation.

On 23 July 2008, JD and SS were conducting surveys of potentially new roosting sites for Semipalmated Sandpipers at a remote location (Farrier's Cove $\left.45^{\circ} 44^{\prime} \mathrm{N}, 64^{\circ} 33^{\prime} \mathrm{W}\right)$ on the western tip of the Cape Maringouin peninsula at the southern boundary of Shepody Bay. Farrier's Cove consists of a $400 \mathrm{~m}$ long mud and cobble beach that is mostly covered during the very highest tides. The long axis of the beach, oriented NNE by SSW Magnetic, is bordered by a steep $15 \mathrm{~m}$ vegetated embankment while the shoulders of the cove, and adjacent headlands, consist of $15 \mathrm{~m}$ cliffs composed of many layers of Carboniferous sandstone.

During the observation period, high tide $(12.4 \mathrm{~m})$ was at $16: 23$, temperature was mild $\left(17-22^{\circ} \mathrm{C}\right.$, wind $\mathrm{NE} 9 \mathrm{~km} / \mathrm{hr}$ ), and water very calm. On arrival (by JD and SS) at 15:23 about 3000 Semipalmated Sandpipers were observed flying over Farrier's Cove and appeared to be attempting to roost at the northern end of the beach. By 15:53, the flock had increased to approximately 10000 birds; although many attempts were made, no birds actually landed at the site. At 16:23 (high tide), approximately 600 sandpipers finally landed on the southern end of the beach but remained for less than ten minutes. At 16:33 a flock of 257 Semipalmated Sandpipers settled on a near-vertical sandstone cliff $(\sim 15 \mathrm{~m})$ (Figure 1). At the same time, an additional 162 birds were observed roosting, in dense clusters, on large sandstone boulders which protruded above the water's surface, adjacent to the aforementioned cliff face. The shorebirds remained motionless on the cliff face for over 30 minutes and were still present when the observations ended at 17:03.

Cliff-roosting by Semipalmated Sandpipers has never before been recorded in Shepody Bay nor reported in the literature, and is uncharacteristic of what has been considered as a 'typical' roosting site (see Gratto-Trevor 1992). This suggests that this behavior is either (i) very uncommon, (ii) a new activity, or (iii) the renewal of what might have been common prior to the re-introduction of the Peregrine Falcons. Small flocks of shorebirds using remote areas and habitats such as sandstone cliffs may provide added protection against what is a comparatively new (re-introduced) avian predator (Peregrine Falcon) in the Bay of Fundy. It is also possible that the type of roost-site 
selection documented here is reflective of roosting behavior when falcons were common in the Bay of Fundy in the early decades of the $20^{\text {th }}$ century (before the reproductive decline attributed to organochlorine pesticide use after World War II); if so, such cliffroosting behavior in small flocks, as documented in this paper, may once again become more common. This potential shift from large roosts on open beaches to smaller more dispersed sites, has major implications for conservation efforts which have been directed towards securing critical habitat adjacent to the 'traditional' roosting sites within Shepody Bay.

\section{Acknowledgments}

We thank Vanessa Roy-MacDougall and Nature New Brunswick for field assistance and Denise Roy, Stacey MacDonald, Stephanie Morris, Sydney Bliss, Margot Elliot and Mathew Park of the Nature Conservancy of Canada Shorebird Interpretation Centre at Johnson's Mills for assistance in shorebird monitoring during the summer of 2008. We thank Environment Canada, Canadian Wildlife Service, summer students, Adam MacPherson, Jeff Atkinson and Darren Ogden for assisting in shorebird surveys at Mary's Point. We thank the New Brunswick Wildlife Trust Fund for its support of this project. We also thank Paul Chamberland, Anthony J. Erskine, Nancy (Lutz) MacKinnon and one anonymous reviewer for commenting on earlier drafts of this paper.

\section{Documents Cited (marked * in text)}

Hicklin, P. W. 1981. Nomads of the Air, the Sandpipers of Fundy. In: Tantramar Magazine, Number 1 (September) 1981, Tantramar Publishing Limited, Sackville, New Brunswick [pages 22-26].

RAMSAR Sites of Atlantic Canada. 1994. Environment Canada, Canadian Wildlife Service, Atlantic Region, 42 pages.

\section{Literature Cited}

Amirault, D. L. 1997. Bay of Fundy Peregrine Falcons. In: The Northwind, Newsletter of the Holliday Beach Migration Observatory 12(2): 21-23 [Spring 1997]

Amirault, D. L. 2003. An overview of recovery and trends in Bay of Fundy Peregrine Falcons, Environment Canada, Canadian Wildlife Service, Bird Trends (9): 63-65.

Beauchamp, G., and G. D. Ruxton. 2008. Disentangling risk dilution and collective detection in the antipredator vigilance of semipalmated sandpipers in flocks. Animal Behaviour 75: 1837-1842.

Boates, J. S. 1980. Foraging Semipalmated Sandpipers Calidris pusilla L. and their major prey Corophium volutator (Pallas) on the Starrs Point mudflat, Minas Basin. M.Sc. thesis, Acadia University, Wolfville, Nova Scotia. 199 pages.

Campbell, A. 1999. Predation success of Peregrine Falcons (Falco peregrinus) and Merlins (Falco columbarius) on the Semipalmated Sandpiper (Calidris pusilla) at high and low flock densities in the Upper Bay of Fundy. Unpublished B.Sc. Special Topics (Biology), Mount Allison University, Sackville, New Brunswick. 39 pages.

Conklin, J. R., M. A. Colwell, and N. W. Fox-Fernandez. 2008. High variation in roost use by Dunlin wintering in California: Implications for habitat limitation. Bird Conservation International 18: 275-291

Elliot, R. D. 1977. Roosting patterns and daily activity of migratory shorebirds at Grand Pré, Nova Scotia. Unpublished M.Sc. thesis, Acadia University, Wolfville, Nova Scotia, 157 pages.

Gratto-Trevor, C. L. 1992. Semipalmated Sandpiper. In The Birds of North America, (6). Edited by A. Poole, P. Stettenheim, and F. Gill. The Academy of Natural Sciences, Philadelphia; The American Ornithologist' Union, Washington, D.C.

Harrington, B. A., and R. I. G. Morrison. 1979. Semipalmated Sandpiper migration in North America. Pages 83-100 in Shorebirds in Marine Environments. Edited by F. A. Pitelka. Studies in Avian Biology 2, Cooper Ornithological Society.

Hicklin, P. W. 1987. The migration of shorebirds in the Bay of Fundy. Wilson Bulletin 99: 540-570.

Hicklin, P. W. 1988. Shepopdy Bay, Bay of Fundy; the first hemispheric shorebird reserve in Canada. Wader Study Group Bulletin 52: 14-15.

Hicklin, P. W., and P. C. Smith. 1979. The diets of five species of migrant shorebirds in the Bay of Fundy. Proceedings of the Nova Scotia Institute of Science 29: 483488.

Hicklin, P. W., and P. C. Smith. 1984. Selection of foraging sites and invertebrate prey by migrant Semipalmated Sandpiper Calidris Pusilla (Pallas) in Minas Basin, Bay of Fundy. Canadian Journal of Zoology 62: 2201-2210.

Morrison, R. I. G. 1977. Use of the Bay of Fundy by shorebirds. Pages 187-199 in Workshop proceedings - Fundy Tidal Power and the Environment. Edited by G. R. Daborn, Acadia University, Wolfville, Nova Scotia.

Sprague, A. J. 2006. Factors affecting movement and habitat selection of Semipalmated Sandpiper (Calidris pusilla Linnaeus) migrating through the upper Bay of Fundy, Canada. Unpublished M.Sc. thesis, The University of New Brunswick, Fredericton, New Brunswick. 81 pages.

Sprague, A. J., D. J. Hamilton, and A. W. Diamond. 2008. Site safety and food affect movements of Semipalmated Sandpipers (Calidris pusilla) migrating through the upper Bay of Fundy. Avian Conservation and Ecology - Écologie et conservation des oiseaux 3(2): 4 [online: URL: http://www.ace-eco.org/vol3/iss2/art4/].

Received 16 October 2008

Accepted 2 July 2009 